\title{
The Nutrition Waste Vegetables with Invitro Using Rumen Liquids for Feed
}

\author{
Murni $^{1}$, Haryati ${ }^{2}$, Siti Aslamyah ${ }^{2}$, Herry Sonjaya ${ }^{3}$ \\ ${ }^{1}$ Doctoral Program of Agricultura science, Hasanuddin University, Makassar, Indonesia \\ ${ }^{2}$ Faculty of Marine and Fisheries Sciences, Hasanuddin University, Makassar, Indonesia \\ ${ }^{3}$ Faculty of Animal Husbandry, Hasanuddin University, Makassar, Indonesia
}

\section{Email address:}

murni@unismuh.ac.id(Murni)

\section{To cite this article:}

Murni, Haryati, Siti Aslamyah, Herry Sonjaya. The Nutrition Waste Vegetables with Invitro Using Rumen Liquids for Feed. Journal of Food and Nutrition Sciences. Vol. 6, No. 2, 2018, pp. 58-62. doi: 10.11648/j.jfns.20180602.13

Received: March 11, 2018; Accepted: March 24, 2018; Published: April 16, 2018

\begin{abstract}
Rumen fluid has enormous potential in reducing fiber content; it can utilize in hydrolyzing vegetable waste containing cellulose. This study aims to analyze the nutrition of vegetable waste invitro using rumen fluid. This research uses a factorial pattern with the complete randomized complete design. The first factor was the dosage of rumen fluid $1 \%, 2 \%, 3 \%$, and the second element was four days, six days, eight days, ten days in the process of fermentation of vegetable waste. The results showed that fermentation of vegetable waste with rumen fluid dose, length of incubation time, and interaction were both significant $(\mathrm{P}<0.05)$ affecting crude fiber content and carbohydrate content of the vegetable waste. The single-acting dose of the rumen fluid, the incubation time of the vegetable waste, and the combination of both had no significant effect $(\mathrm{P}>0.05)$ on the crude fat content. The different rumen fluid dose treatment on the vegetable waste had a significant impact $(p<0.05)$ to the crude protein content. But not the time of fermentation $(\mathrm{p}>0.05)$ and the interaction of both ( $>>0.05)$. The results concluded that to produce quality nutrition of vegetable waste should be fermented by using dose $3 \%$ rumen liquid and four days incubation.
\end{abstract}

Keywords: Vegetable Waste, Rumen Fluid, Feed, Fermentation

\section{Introduction}

Rumen fluid is an animal slaughterhouse, and its availability is very abundant which will pollute the environment if not handled properly. While rumen fluid has enormous potential in reducing fiber content because the rumen fluid microorganism contains cellulase and amylase enzymes capable of hydrolyzing the feed (Andriani, 2015). Therefore, rumen fluid has the potential to decrease the fiber of vegetable waste as feed raw material.

The vegetable waste contains water that is high enough that easily damaged and pollute the environment. So far, vegetable waste is only used as raw material for animal feed, while for aquatic organisms feed has not been utilized. Seeing the potential of vegetable waste is so great, it is necessary to further examine its utilization opportunities as vannamei shrimp feed ingredients. The vegetable waste contains crude protein $22.63 \%$, crude fiber $30.71 \%$.
However, in the utilization of vegetable waste is constrained on high cellulose content (Murni and Darmawati, 2016), thus inhibiting the digestibility of feed (Dedi Jusadi et al., 2013). To overcome cellulose content use rumen fluids capable of hydrolyzing fibers through the incubation process, since rumen fluid produces cellulase, amylase, protease, fitase, and lipase enzymes (Fitriliyani, 2011); rumen ox fluid contains cellulase, amylase, protease, xylanase, mannanase, and fitase (Lee et al., 2002). Further Martin et al. (1999) explained that carbohydrate digesting enzymes in rumen fluid include amylase, xylanase, avicelase, $\alpha$-D-glucosidase, $\alpha$-Larabinofuranosidase, $\beta$-D-glucosidase, and $\beta$-D-xylosidase, whereas according to Budiansyah (2010), that rumen fluid contains cellulase, xylanase, mannanase, amylase, protease, and fitase enzymes capable of hydrolyzing local feed ingredients.

The study was reported by (Budiansyah et al. 2011), that rumen fluid enzyme with an optimum dose of $2.5 \%$ able to hydrolyze local rice bran, soybean meal and copra flour for 
cassava flour and palm kernel powder optimum dose $2.0 \%$, for soybean-based broiler feed is $1.0 \%$. The use of rumen fluid in the vegetable fermentation process of $10-15 \mathrm{~mL} / \mathrm{kg}$ can increase the nutrient content of fermented vegetable waste for tilapia feed and increase the activity of amylase enzyme $(0.250 \mathrm{u} / \mathrm{ml} / \mathrm{min})$, protease $(0.49 \mathrm{u} / \mathrm{ml} /$ minute $)$, cellulase $(0.124 \mathrm{u} / \mathrm{ml} / \mathrm{min}$ ) (Murni and Darmawati, 2016). Based on this, the use of rumen fluid is expected to hydrolyze crude fiber vegetable waste is high so that it can improve the digestibility of feed. This study aims to analyze the nutrition of vegetable waste invitro using rumen fluid as feed raw material.

\section{Methods}

\subsection{Time and Place}

This research conducted at the Laboratory of Research Center of Maros Brackish Water Research Development, Laboratory of Animal Feed and Chemistry of Unhas Agriculture Faculty. The study was conducted for two months, starting from September 2016 until November 2017.

\subsection{Research Procedure}

\subsubsection{Preparation of Rumen Fluid}

Cow rumen fluid took from the Sungguminasa Animal Slaughterhouse of Gowa Regency. Cow's rumen fluid is made from the cow rumen contents by filtration (filtering with a cotton cloth) at a temperature of $40 \mathrm{C}$. The extract of rumen fluid enzyme extract is obtained by method Lee et al., (2002).

\subsubsection{Fermentation Process Vegetable Waste}

Vegetable waste used in the study is mustard, cabbage, kale, and carrots obtained from the market of Sungguminasa, Gowa regency $25 \%$ each. The research begins with a rough cut of vegetable waste and milled. Vegetable waste inserted into the plastic clip added $10 \%$ molasses and rumen fluid with a dose of $1,2,3 \%$ tightly sealed and incubated with periods of 4, 6, 8 and ten days anaerobically, then stored in a box to keep the room temperature equal. After the incubation process is finished stored in the freezer to stop the action of the rumen fluid enzyme, then chemically analyzed in the laboratory.

\subsubsection{Quality Analysis of Vegetable Waste}

The report of the quality of fermented vegetable waste using rumen fluid with different incubation time analyzed at the end of the study including protein content, fat content, fiber content, carbohydrate content concerning AOAC method (2005).

\subsection{Data Analysis}

The data obtained from the test results proximate, analyzed using analysis variance. If the treatment has a real effect, then proceed with Duncan Test.

\section{Results}

Rough Protein Content of Vegetable Waste Treatment of different rumen fluid dose on vegetable waste had significant effect $(p<0.05$ ) on crude protein content, but not with fermentation time $(p>0.05)$ and interaction of both $(p>0.05)$. The average rough protein content of rumen fermented liquid is presented in Table 1.

Table 1. Average rough protein of vegetable waste from rumen fermentation.

\begin{tabular}{ll}
\hline Rumen Fluid Dose & Rough protein Vegetable Waste \\
\hline $1 \%$ & $18.395 \mathrm{a}$ \\
$2 \%$ & $19.844 \mathrm{~b}$ \\
$3 \%$ & $20.401 \mathrm{~b}$ \\
\hline
\end{tabular}

Description: the average value in the same column followed by different letters of the superscript shows significantly different values $(p<0.05)$.

The Duncan test of the rumen fluid dosage to the crude protein content of the vegetable waste showed that the $1 \%$ dosage of the crude protein was lower and different from the $2 \%$ and $3 \%$ doses, but the $2 \%$ and $3 \%$ rumen fluid dosage treatment was the same.

Levels of Crude Fiber Vegetable Waste

The crude fiber content of fermented vegetable waste is presented in Table 2. The result of the variance analysis showed that the rumen fluid dosage treatment and the incubation time had a significant effect $(p<0.05)$ and there was an interaction between the two on the crude fiber content of the vegetable waste. The Duncan test results showed that the crude fiber content of the vegetable waste in the $3 \%$ incubation treatment of $4,6,8$, and ten days incubation were not different, but lower than the other treatments. The crude fiber content of vegetable waste at $1 \%$ incubation treatment 4 and six days, $2 \%$ incubation four days is not different, but higher than other treatments. The interaction between doses of rumen fluid with length of incubation time against crude fiber content (\%) Vegetable Waste is presented in Figure 1.

Table 2. Raw fiber content levels of rumen fermented vegetable waste in all treatment combinations.

\begin{tabular}{ll}
\hline Treatment Combination & Rough Fiber Content (\%) \\
\hline $1 \%$ 4 days & $16.26 \pm 0.22^{\mathrm{g}}$ \\
$1 \% \_6$ days & $15.71 \pm 0.09^{\mathrm{g}}$ \\
$1 \% \_8$ days & $14.65 \pm 0.23^{\mathrm{ef}}$ \\
$1 \% \_10$ days & $13.74 \pm 0.07^{\mathrm{cd}}$ \\
$2 \% \_4$ days & $15.81 \pm 0.09^{\mathrm{g}}$ \\
$2 \% \_6$ days & $14.52 \pm 0.41^{\mathrm{de}}$ \\
$2 \% \_8$ days & $13.42 \pm 0.00^{\mathrm{bc}}$ \\
$2 \% \_10$ days & $13.22 \pm 0.35^{\mathrm{bc}}$ \\
$3 \% \_4$ days & $11.79 \pm 0.86^{\mathrm{a}}$ \\
$3 \%-6$ days & $11.56 \pm 0.77^{\mathrm{a}}$ \\
$3 \% \_8$ days & $12.33 \pm 0.00^{\mathrm{a}}$ \\
$3 \% \_10$ days & $12.73 \pm 0.02^{\mathrm{ab}}$ \\
\hline
\end{tabular}

Description: The result of analysis of the various treatment combinations had significant effect $(\mathrm{P}<0.05)$ on the crude fiber content of vegetable waste from rumen fermentation. 


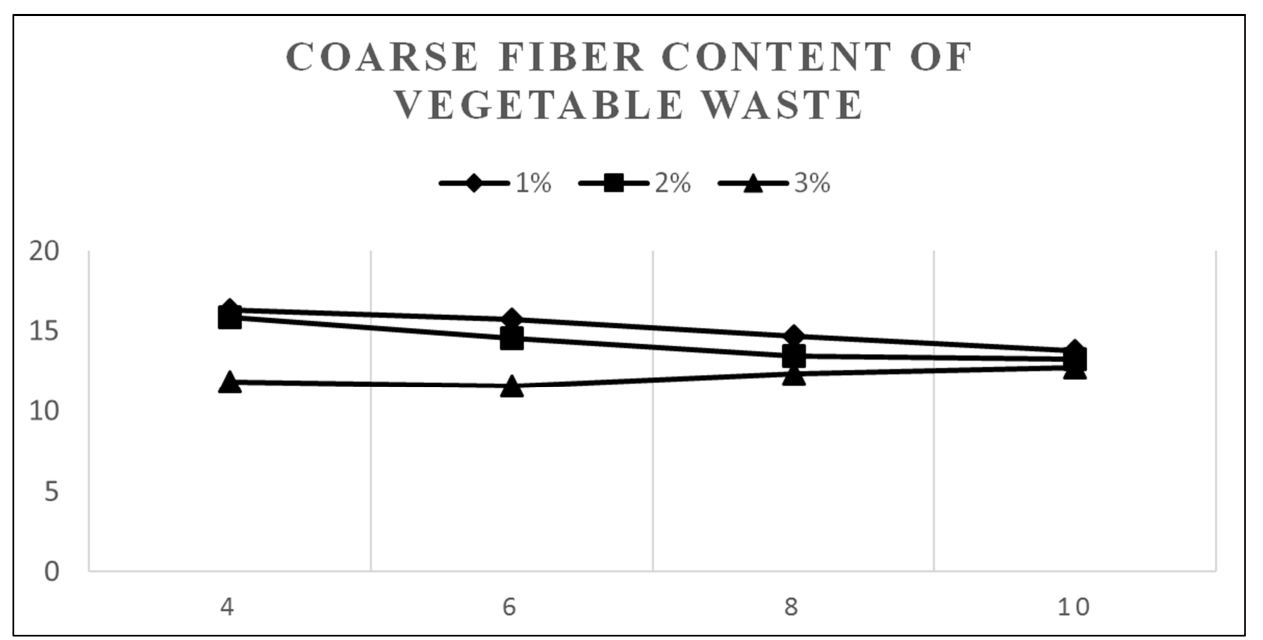

Figure 1. Interaction between doses of rumen fluid with length of incubation time on crude fiber content (\%) Vegetable Waste.

Figure 1 shows that oil fiber of vegetable waste in rumen fluid dose treatment is $1 \%$ and $2 \%$ higher than $3 \%$ dose. But at incubation time six days to 10 days, there is a decrease of crude fiber at $1 \%$ dose and $2 \%$ rumen fluid, whereas dose $3 \%$ relative elevated levels of oil fiber to 10 days incubation time.

\section{Raw Fatty Content of Vegetable Waste}

The rough fat content of vegetable waste from rumen fluid fermentation in all treatment combinations is presented in Table 3. Variance analysis showed that both single-dose rumen fluid, an incubation time of vegetable waste and a combination of both had no significant effect $(\mathrm{P}>0.05)$ on fat content rude.

Table 3. Raw fat content of vegetable waste from rumen fluid fermentation in all treatment combinations.

\begin{tabular}{ll}
\hline $\begin{array}{l}\text { Treatment } \\
\text { combination }\end{array}$ & $\begin{array}{l}\text { Rough fat content of vegetable waste from rumen } \\
\text { fermentation }(\%)\end{array}$ \\
\hline 1\%_4 days & $3.33 \pm 0.17$ \\
1\%_6 days & $3.53 \pm 0.02$ \\
1\%_8 days & $3.52 \pm 0.72$ \\
1\%_10 days & $3.03 \pm 0.23$ \\
2\%_4 days & $3.26 \pm 0.07$ \\
\%\%_6 days & $3.30 \pm 0.19$ \\
2\%_8 days & $3.75 \pm 0.12$ \\
2\%_10 days & $3.44 \pm 0.44$ \\
3\%_4 days & $3.60 \pm 0.28$ \\
3\%-6 days & $3.44 \pm 0.28$ \\
3\%_8 days & $3.27 \pm 0.23$ \\
3\%_10 days & $3.05 \pm 0.29$ \\
\hline
\end{tabular}

Description: The result of analysis of the various combination of treatment has no significant effect $(\mathrm{P}>0.05)$ to the crude fat content of vegetable waste from rumen fluid fermentation.

Based on Table 3, it shows that the doses of rumen fluid 1, 2 , and $3 \%$ with an incubation time of $4,6,8$, ten days give the same effect to the crude fat content of the vegetable waste.

Carbohydrate content of vegetable waste
The level of vegetable waste carbohydrate produced by rumen fluid fermentation in all treatment combinations is presented in Table 4.

Table 4. Carbohydrate content of vegetable waste from rumen fluid fermentation in all treatment combinations.

\begin{tabular}{ll}
\hline Treatment Combination & Content of Non-Nitrogen Extracts $(\%)$ \\
\hline 1\%_4 days & $34.89 \pm 0.09^{\mathrm{b}}$ \\
1\%_6 days & $35.61 \pm 0.67^{\mathrm{b}}$ \\
1\%_8 days & $33.75 \pm 0.13^{\mathrm{b}}$ \\
1\%_10 days & $29.25 \pm 0.71^{\mathrm{a}}$ \\
2\%_4 days & $35.67 \pm 3.22^{\mathrm{b}}$ \\
2\%_6 days & $36.21 \pm 0.98^{\mathrm{b}}$ \\
2\%_8 days & $35.86 \pm 1.57^{\mathrm{b}}$ \\
2\%_10 days & $30.60 \pm 0.86^{\mathrm{a}}$ \\
$3 \% \_4$ days & $39.85 \pm 0.76^{\mathrm{cd}}$ \\
$3 \%$-6 days & $38.71 \pm 0.86^{\mathrm{bc}}$ \\
$3 \% \_8$ days & $36.01 \pm 2.69^{\mathrm{b}}$ \\
$3 \% \_10$ days & $34.61 \pm 0.84^{\mathrm{b}}$ \\
\hline
\end{tabular}

Description: The analysis of various treatment combinations had a significant effect $(\mathrm{P}<0.05)$ on BETN content of vegetable waste from rumen fermentation.

The result of variance analysis showed that rumen fluid dose treatment and incubation time had a significant effect ( $p$ $<0.05$ ) and there was an interaction between the two on the carbohydrate content of the vegetable waste. Duncan test results showed that carbohydrate levels in the treatment of $3 \%$ incubation dose four days different and significantly higher than the other treatment. Carbohydrate content of vegetable waste in treatment dose $1 \%$ incubation ten days, and $2 \%$ incubation ten days same, but lower than other treatment. The interaction between the rumen fluid dose and the length of incubation time against the content of the extracted material without nitrogen (\%) of vegetable waste is presented in Figure 2. 


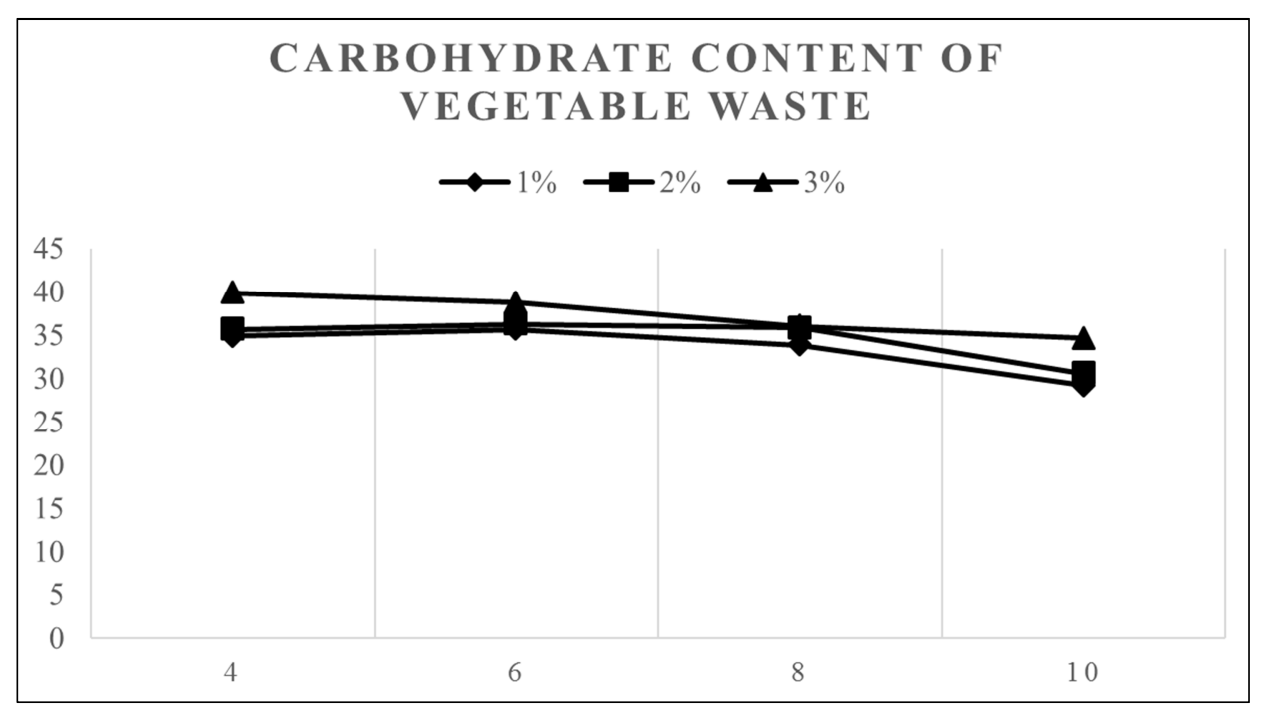

Figure 2. Interaction between rumen fluid dosage and length of incubation time on extract content without nitrogen (\%) of vegetable waste.

The interaction relationship between the rumen fluid dose and the duration of the incubation period (Figure 2) showed that the carbohydrate content of the vegetable waste at the $1 \%$ and $2 \%$ incubation treatments of four and six days significantly lower, but the dose $3 \%$ higher. Subsequently, there was a decrease in carbohydrate levels at 8 and ten days incubation at all rumen fluid dose treatments, but the $3 \%$ dose remained higher than other treatments.

\section{Discussion}

High levels of protein at a dose of $3 \%$ were due to the higher doses of rumen fluid, making protease enzyme activity more optimal in hydrolyzing the protein content of vegetable waste in the presence of rumen fluid protease enzymes (Fitriliyani, 2010). The results of research Murni and Darmawati (2016) obtained amylase enzyme activity $(0.250 \mathrm{u} / \mathrm{ml} / \mathrm{min})$, protease $(0.49 \mathrm{u} / \mathrm{ml} / \mathrm{min})$, and cellulase $(0.124 \mathrm{u} / \mathrm{ml} / \mathrm{min})$ on the use of rumen cow fluid in the process fermentation of vegetable waste. The occurrence of a decrease in the crude protein content of vegetable waste produced in rumen fluid doses of $1 \%$ and $2 \%$ compared with $3 \%$ is due to the lower added rumen fluid dose resulting in low enzyme activity. Dolinska et al. (2012) suggest that enzyme type and incubation time affect the efficiency of hydrolysis and protein concentration.

The high fiber roughage of vegetable waste in the treatment of dose $1 \%$ and $2 \%$ of rumen fluid during the incubation process due to the added dose is lower, so the cellulase enzyme activity of rumen fluid is also not maximal and takes longer in hydrolyzing the fiber of vegetable waste. This is in line with Elwakeel et al. (2007); Alvarez et al., (2009), that fiber hydrolysis is affected by the interaction between enzymes, substrates and incubation periods. The low level of crude fiber content of vegetable waste at $3 \%$ dose with four days incubation time due to higher prescription added, so with four days incubation time cellulase enzyme from rumen fluid has been able to degrade the complex fiber content in vegetable waste becomes more straightforward. The study is in line with the results of the by Murni et al. (2017) obtained the lowest crude fiber content of vegetable waste at four days incubation time. This is due to the synergistic and complex interactions of the cellulase enzyme and the xylanase enzyme (Trinci et al., 1994) (Lee et al., 2002).

Based on Table 3 shows no effect $(\mathrm{P}>0.05)$ on fat content of vegetable waste, caused by lipase enzyme activity in rumen fluid lower, so it is not maximal in hydrolyzing vegetable fat during fermentation by rumen fluid enzyme (Nalar, 2014). Fitriliani (2010) obtained lower lipase enzyme activity $(0.01 \pm 0.00 \mathrm{IU} / \mathrm{ml} / \mathrm{min})$ and larger cellulase (1.66 $\pm 0.19 \mathrm{IU} / \mathrm{ml} / \mathrm{min})$; amylase $(1.32 \pm 0.02 \mathrm{IU} / \mathrm{ml} / \mathrm{min})$; fitase $(0.27 \pm 0.13 \mathrm{IU} / \mathrm{ml} / \mathrm{min})$; protease $(0.26 \pm 0.07 \mathrm{IU} /$ $\mathrm{ml} / \mathrm{min}$ ); on rumen fluid of sheep.

The low level of vegetable waste carbohydrate at doses 1 and $2 \%$ with an incubation time of $4,6,8$ and ten days is due to the addition of rumen fluid dose is lower than $3 \%$ treatment so that at incubation time is not maximal hydrolyzed vegetable waste caused by low amylase enzyme activity. This is in line with Giraldo et al., (2008), suggesting that enzyme activity varies depending on proportion and concentration, a dose of the enzyme (Jalilvand et al., 2008). (Budiansyah et al. 2011), stated that rumen fluid enzyme with an optimum dose of $2.5 \%$ able to hydrolyze the local feed ingredients of rice bran, soybean flour, and copra flour, for cassava flour and palm kernel powder optimum dosage of rumen fluid $2.0 \%$, and $1.0 \%$ soybean-based broiler feed.

\section{Conclusion}

The research concluded that vegetable waste from rumen fermented liquid with different incubation time produced the highest levels of protein, fiber content, fat content, and carbohydrate level in 3\% dose treatment with four days incubation time. 


\section{References}

[1] AOAC. 2005. Official Methods of Analysis The Association of Official Analytical Chemist. 18thed. Marylad: AOAC International. William Harwitz (ed).

[2] Alvarez, G., Pinos-Rodríguez, J. M., Herrera, J. G., García, J. C., Gonzalez, S. S., \& Barcena, R. (2009). Effects of exogenous fibrolytic enzymes on ruminal digestibility in steers fed high fiber rations. Livestock Science, 121 (2), 150154. DOI:https: // doi. org/ 10. 1016/j. livsci. 2008. 05. 024.

[3] Andriani, Y. (2015). Assessment Of Cow Rumen Fluid Cellulose-Amylase Enzyme Activity As An Alternative Source Of Crude Fiber Degrading Enzyme In Fish Feed Materials. Lucrări Științifice-Universitatea de Științe Agricole și Medicină Veterinară, Seria Zootehnie, 63, 242-245. http://www.uaiasi.ro.

[4] Budiansyah, A., Resmi, B., Wiryawan, K., Soehartono, D., Widyastuti, Y., \& Ramli, N. (2010). Isolasi dan Karakterisasi Enzim Karbohidrase Cairan Rumen Sapi Asal Rumah Potong Hewan. Media Peternakan, 33 (1), 31. Retrieved from http://mail.student.ipb.ac.id/index.php/mediapeternakan/articl e/view/1225.

[5] Budiansyah, A., m i, R., w i, N., Suhartono, M., Wiryawan, K., \& Widiastuti, Y. (2012). Hidrolisis zat makanan pakan oleh enzim cairan rumen sapi asal rumah potong hewan. Agrinak. Jurnal Agribisnis Dan Industri Peternakan,, 17-24. Retrieved from https://onlinejournal.unja.ac.id/index.php/Agrinak/article/view/3.

[6] Dolińska, B., Zieliński, M., Dobrzański, Z., Chojnacka, K., Opaliński, S., \& Ryszka, F. (2012). Influence of incubation conditions on hydrolysis efficiency and iodine enrichment in baker's yeast. Biological trace element research, 147 (1-3), 354-358. https://doi.org/10.1007/s12011-011-9318-0.

[7] Jusadi, D., Ekasari, J., \& Kurniansyah, A. (2014). Improvement of cocoa-pod husk using sheep rumen liquor for tilapia diet. Jurnal Akuakultur Indonesia, 12 1), 40-47. DOI: http://dx.doi.org/10.19027/jai.12.40-47.

[8] Elwakeel, E. A., Titgemeyer, E. C., Johnson, B. J., Armendariz, C. K., \& Shirley, J. E. (2007). Fibrinolytic Enzymes to Increase the Nutritive Value of Dairy Feedstuffs1. Journal of Dairy Science, 90 (11), 5226-5236. DOI: https://doi.org/10.3168/jds.2007-0305.

[9] Fitriliyani, I. (2010). Evaluation of the nutritional value of Leucaena leucophala leaf meal hydrolyzed by sheep rumen liquor enzyme extract on the growth performance of Nile tilapia (Oreochromis niloticus). Jurnal Akuakultur Indonesia, 9 (1), 30-37. DOI: http://dx.doi.org/10.19027/jai.9.30-37.

[10] Fitriliyani, I., Harris, E., \& Nahrowi, N. (2010). Peningkatan Kualitas Nutrisi Tepung Daun Lamtoro Sebagai Pakan Ikan Dengan Penambahan Ekstrak Enzim Cairan Rumen Domba [Improvement Nutrition Value of Leucaena Leaf Meal as Fish
Feed with Addition of Sheep Rumen Fluid Enzyme]. Berita Biologi, 10 (2). DOI:

http://dx.doi.org/10.14203/beritabiologi.v10i2.1965.

[11] Giraldo, L. A., Tejido, M. L., Ranilla, M. J., Ramos, S., \& Carro, M. D. (2008). Influence of direct-fed fibrolytic enzymes on diet digestibility and ruminal activity in sheep fed a grass hay-based diet 1. Journal of Animal Science, 86 (7), 1617-1623..

https://dl.sciencesocieties.org/publications/jas/abstracts/86/7/0 861617.

[12] Jalilvand, G., Odongo, N. E., López, S., Naserian, A., Valizadeh, R., Shahrodi, F. E.,... \& France, J. (2008). Effects of different levels of an enzyme mixture on in vitro gas production parameters of contrasting forages. Animal Feed Science and Technology, 146 (3-4), 289-

301.https://doi.org/10.1016/j.anifeedsci.2008.01.007.

[13] Lee, S. S., Kim, C. H., Ha, J. K., Moon, Y. H., Choi, N. J., \& Cheng, K. J. (2002). Distribution and activities of hydrolytic enzymes in the rumen compartments of Hereford bulls fed alfalfa-based diet. Asian Australasian Journal Of Animal Sciences, 15 (12), 1725-1731.

https://www.ajas.info/upload/pdf/15_274.pdf.

[14] Martin, C., Devillard, E., \& Michalet-Doreau, B. (1999). Influence of sampling site on concentrations and carbohydrate-degrading enzyme activities of protozoa and bacteria in the rumen. Journal of animal science, 77 (4), 979987.

https://dl.sciencesocieties.org/publications/jas/abstracts/77/4/9 79.

[15] Murni and Darmawati, 2016. Optimize the use of Liquid Rumen in Fermentation Process on Increased the Nutrients Waste Vegetables For Tilapia 'S Feed. International Journal of Oceans and Oceanography ISSN 0973-2667 Volume 10, Number 1 (2016), pp. 19-28. https://www.ripublication.com/ijoo16/ijoov10n1_03.pdf.

[16] Murni, Darmawati, Muhammad Irwandi Amri. 2017. Optimasi Lama Waktu Fermentasi Limbah Sayur dengan Cairan Rumen terhadap Peningkatan Kandungan Nutrisi Pakan Ikan Nila Oreochromis niloticus. Jurnal Octopus Volume 6. Nomor 1.

http://journal.unismuh.ac.id/index.php/octopus/article/view/68 0 .

[17] Nalar, H. P, Herliani, Irawan, B., Rahmatullah, S. N., Askalani, Kurniawan, N. M. A., 2014. Pemanfaatan Cairan Rumen dalam Proses Fermentasi Sebagai Upaya Peningkatan Kualitas Nutrisi Dedak Padi Untuk Pakan Ternak. Prosiding Seminar Nasional "Inovasi Teknologi Pertanian Spesifik Lokasi”. Banjar Baru 6- 7 Agustus 2014.

[18] Trinci, A. P., Davies, D. R., Gull, K., Lawrence, M. I., Nielsen, B. B., Rickers, A., \& Theodorou, M. K. (1994). Anaerobic fungi in herbivorous animals. Mycological Research, 98 (2), 129-152. https://doi.org/10.1016/S09537562 (09) 80178-0. 